\title{
Lumen
}

Selected Proceedings from the Canadian Society for Eighteenth-Century Studies

\section{Literary Experiment and Female Infamy: Lady Mary Wortley Montagu fictionalizes her life}

\section{Isobel Grundy}

Volume 31, 2012

URI : https://id.erudit.org/iderudit/1013064ar

DOI : https://doi.org/10.7202/1013064ar

Aller au sommaire du numéro

Éditeur(s)

Canadian Society for Eighteenth-Century Studies / Société canadienne d'étude du dix-huitième siècle

ISSN

1209-3696 (imprimé)

1927-8284 (numérique)

Découvrir la revue

Citer cet article

Grundy, I. (2012). Literary Experiment and Female Infamy: Lady Mary Wortley

Montagu fictionalizes her life. Lumen, 31, 1-20.

https://doi.org/10.7202/1013064ar 


\title{
Literary Experiment and Female Infamy: Lady Mary Wortley Montagu fictionalizes her life
}

\author{
ISOBEL GRUNDY
}

University of Alberta

This article relates to one entitled "Medical Advance and Female Fame," which also originated as a CSECS plenary paper in St. John's, NL (1992). That dealt with Lady Mary Wortley Montagu's role in a great public event, the arrival in western medicine of the practice of securing immunity against smallpox by inoculation with the actual virus (technically called variolation). This was the first time that scientific medicine, as distinct from folk practice, had produced immunity through antibodies: a significant step in the Whig narrative of progress which is the history of western medicine. ${ }^{1}$

For Montagu inoculation brought celebrity as the saviour of hundreds of lives. She was hailed in print by such luminaries as Voltaire and honoured with a memorial plaque in Lichfield Cathedral. The mark she made in the public sphere was just the highest point in a high-profile career. She had been toasted by the male elite of the KitCat Club at eight and had repeatedly made the newspapers: with her elopement, her court satires, and her choosing to share her husband's ambassadorial journey to Turkey instead of waiting for him at home. Apart from headline moments, she became well-known for unpublished writings. On her last return to England from abroad she was lionized by upper-class Londoners anxious for a glimpse of her. Female fame indeed.

1. Isobel Grundy, "Medical Advance and Female Fame: Inoculation and its After-Effects," Lumen 13 (1994): 13-42. 
But Montagu's moment of glory also luridly highlighted the downside of female fame. Hailed as a saviour by some, she was attacked by the anti-inoculation faction as more or less a mass murderer. She feared that the medical witnesses inspecting her recently-inoculated small daughter might sabotage the experiment by secretly harming the child. She was badgered for support by nervous parents who faced family opposition in their desire to inoculate their children. She was abused in print in viciously gendered language by those who believed inoculation to be against nature or against the will of God. Female infamy, indeed.

The glittering thread of fame in Lady Mary's life story is interwoven with a darker one of concealment, secrecy, willed invisibility. Her actual life was full of concealments, from anonymous and pseudonymous publication to her humiliating, unrequited love for Francesco Algarotti. This secret apparently remained unsuspected by any except her friend Lord Hervey. From her and this one confidant the secret evoked extraordinary riddling dialogues, in which these two love-rivals hold the pen alternately and discuss with startling frankness their mutual attempts to hide the truth about themselves while extracting the truth about the other. ${ }^{2}$ Secrets and writing went together in Montagu's life as in her literary output.

This article, in contrast to that of 1994, addresses the darker strand, the dread of ill fame. It centres on one of Montagu's finest literary works: an anti-romance, a philosophic tale in the style of Candide or Rasselas, a coded autobiography, an experimental fiction which would surely have altered the course of the English novel if it had been as widely read as her travel letters or her poetry. I shall read it in terms suggested by Nancy K. Miller as something which is "there, but in opposition to the 'already read', [the] 'sous lu', cut off from the kind of historical and metacritical life that characterizes the works of dominant [traditions]" - traditions in the plural, that is: those of early prose fiction both in English and in French. ${ }^{3}$

2. Lady Mary Wortley Montagu, Essays and Poems with Simplicity, a Comedy, ed. Robert Halsband and Isobel Grundy (Oxford: Clarendon, $2^{\text {nd }}$ ed., 1993): 286-90.

3. Nancy K. Miller, "Men's Reading, Women's Writing: Gender and the Rise of the Novel" in Miller and Joan DeJean, eds., The Politics of Tradition: Placing Women in French Literature (New Haven: Yale UP, 1988: Yale French Studies no. 75, 40-55), 47 , n. 11. 
This work of Montagu's was and is almost unknown. It's untitled, composed not in her native language but in French, not in one of the genres she admired (like poetry, history, drama) but in the low-status form of romance, apparently written in secret and solitude, not mentioned by any of her contemporaries, not rediscovered or printed till the later twentieth century. This is a work which its author buried alive.

It reached print, under the title (from its protagonist) of "Princess Docile," or rather "La Princesse Docile," in 1996, in a volume of Montagu's Romance Writings, which was unfortunately too expensive to get wide exposure. ${ }^{4}$ It is a multi-generic work, both highly unusual and entirely characteristic of its creator. Its tone approaches the Swiftian: in an echo of the king of Brobdingnag, the ruler of the planet Venus (whose son and Docile have fallen in love) pronounces our planet to be one "where an honest man is exposed, all his life, to Warfare as unequal as that of the naked Americans against the Spaniards armed with swords and Guns."

If survival is problematic for an "honnête homme," it is much more so for an honest woman. In women, "honesty" or "virtue" is at this date conventionally defined to mean absence of sexual feeling. Montagu's protagonist, the defenceless Docile, finds herself faced at every turn by corruption, covert self-seeking, and ruthless exploitation of anyone weak enough or idealistic enough to be vulnerable. Docile (Montagu's heavily veiled self-portrait) is not weak but she is an incorrigible idealist. She is a hundred percent virtuous in sexual as in other matters, but not without sexual feeling. To understand the viewpoint that produced this self-portrait it is necessary to consider the personal context of the work before the work itself.

The general perception of Lady Mary is realist rather than idealist and is far from docile. It leans towards boldness, rebelliousness, aristocratic self-confidence, even intellectual arrogance. Writing of herself, however, she paints a different picture. During the courtship that preceded a daring elopement, she ran away from her father's intimidating presence to write to him instead, and she repeatedly assured her future husband of her disinterested integrity, her preference of retirement to

4. Lady Mary Wortley Montagu, Romance Writings, ed. Isobel Grundy, (Oxford: Clarendon 1996), 106-92 (English translation), 211-76 (original).

5. Romance Writings, 134. 
fashionable display, and her desire to make herself whatever he wanted. She consistently paints herself as tender-hearted, fearful, easily hurt. In an autobiographical fairy-tale, "Carabosse" (written, like "Princess Docile," in French), she casts herself as a baby princess whose gifts from good fairies are each negated by a bad fairy's gifts, among which the most painful is acute sensibility to others' troubles. ${ }^{6}$

Montagu's early poem, "Written ex tempore in Company in a Glass Window the first year I was marry'd," strikes a note of moral virtue and submissiveness. It opens with the assertion that "Thirst of Power, and desire of Fame, / In every Age, is every Woman's Aim."7 The power here is power over men; the fame is not literary or scientific, but the celebrity of a reigning beauty. In disclaiming any wish for such power or fame, the speaker says nothing of the drawbacks attached to them, the reversibility of female fame, the threat of infamy. To be good, she seems to expect, means to be safe. In Montagu's more mature writings virtue is not rewarded; it is good deeds which are punished.

Even before "Written ex tempore," she had already treated of ill fame and the concealment and evasion it engenders. One of her teenage poems records being rebuked and punished for writing about love. It balances two conflicting potential outcomes: that she might burn her writing and forget her follies - or else that even "if I Now both burn and blot / (By mee) they cannot be forgot." ${ }^{8}$ Secret evidence may be destroyed but fear of infamy persists. Lady Mary's famous courtship letters echo with the fear of exposure: the first one ends: "I don't injoin you to burn this Letter. I know you will."

With young women friends, meanwhile, her companions on the auction block of the marriage market, Lady Mary used a code for discussing their prospects - Hell for marriage to a man one hates, Paradise for marriage to the beloved, and Limbo for those many marriage prospects which are neither hateful nor desired. The code was a kind of joke or game, which used writing to conceal as well as to communicate; it might be regarded as practice for "Docile," which was

6. Essays and Poems, 153-55.

7. Essays and Poems, 179.

8. Harrowby Manuscripts Trust, Sandon Hall, Stafford: vol. 250, f. 5 .

9. Lady Mary Wortley Montagu, Complete Letters, ed. Robert Halsband (Oxford: Clarendon, 1965-67), 1. 25. 
never communicated and whose self-portrait was, even in the text, concealed.

Of course her correspondents knew the code, but it has impeded later scholarly understanding. One might summarize her statements couched in the code as follows: that she has no hope of Paradise but that with great effort and difficulty she might get to Limbo. ${ }^{10}$ Scholars have been slow to realise or to comment on the very real possibility that when she eloped with Edward Wortley Montagu (Limbo) she was, or very recently had been, passionately in love with somebody else (Paradise).

So, from the first, Lady Mary's writing engaged with those components of the women's literary tradition named by Adrienne Rich as "Lies, Secrets, and Silence." But where Rich writes of the erasure of women's political and historical past, Montagu writes often about the erasure of personal experience. What is unacceptable cannot be said without disguise. For a fourteen-year-old to write about love, for an eligible young woman to correspond with a man or (less seriously) to mock the border-crossing of marriage by equating it with death, were actions liable to severe censure. These early writings illuminate the mechanism whereby oppression produces sometimes concealment and deceit - or, seeing those responses more positively, resistance.

Montagu continued as a seasoned writer both to use and to dwell on concealment and deceit. Her Eclogues, which circulated secretly in manuscript, centre on these themes. The first speaker unburdens herself of her secrets only in the shelter of her sedan chair; the last one is leaving town to "hide in shades."1l The young wife in "Wednesday" is trapped and struggling in a web of social concealment and threat of exposure. The two rakish speakers in "Tuesday" compete by counting the outward and visible signs which expose the secret of their sexual conquests. Through these signs or clues, the poem renders the potentially treacherous gulf between the sign and its esoteric meaning.

In Turkey Montagu describes her delight not only in the secrecy conferred by the veil, but also in the practice of sending small objects imbued with meaning in the place of letters. Her sample love-letter begins with a pearl (which she translates "Fairest of the young") and

10. Complete Letters, 1: 128-29, 149-50.

11. Essays and Poems, 204. 
concludes with pepper ("Send me an Answer"). By this means, she writes, "you may quarrel, reproach, or send Letters of passion, freindship, or Civillity, or even of news, without ever inking your fingers." ${ }^{2}$ Inky fingers are a clue that signals writing; they are practically code for the crime of being a learned lady. A letter in objects leaves no trace.

Several of Montagu's poems treat sexual love (with no mention of marriage) as a dangerous secret. "The Lover. A Ballad" (one of her most anthologized pieces) lays out a woman's specifications for an ideal secret lover. He must "In public preserve the Decorums are just," until the poem's climactic moment, the brief, happy tête-à-tête when "Forgetting or scorning the Airs of the Croud / He may cease to be formal, and I to be proud, / Till lost in the joy we confess that we live...."13 Happiness, even life, depends on secrecy. In a poem about the love of the goddess Diana for Endymion, Montagu writes of the moon coming "Veil'd with the Mantle of concealing Night" to meet her human lover, and in another that contrasts enduring love with short-lived fascinations, she writes: "Deep thô unseen remains the secret wound" where the true love has carved his name..$^{14}$

"Princess Docile" presents the story of a heroine who is virtuous without limit (seeking the good of others before her own), open to love, and eternally victimized. This coded autobiography (of inward rather than outward experience) focuses on the issue of living with secrets, lies, and misrepresentation as the centre of its study of the general human condition. Generically mixed and episodic in plot, it is nevertheless tightly unified by its central themes: the ubiquitous practice of concealment (high-minded in Docile, deceitful in others); the way she is punished for her impeccable obedience to oppressive, internalized rules, and the way that good deeds lead to ill-fame. Each one of Docile's attempts at active goodness provides fuel for those who oppress, misunderstand, and misrepresent her.

Her destiny is formed, like that of the baby princess in "Carabosse," by an ill-fated fairy gift, but this fairy is not malevolent, just bungling and bad-tempered. The fairy's first mistake is to admire the character of Docile's mother, the Queen of the land of Travers (rendered into

12. Complete Letters, 1: $388-89$.

13. Essays and Poems, 235-36.

14. Essays and Poems, 300, 244. 
English as Contrary), and set out to reward her. The queen, too selfcomplacent to feel the need of any gift, ends by wishing for her unborn baby to be dowered with perfect docility or teachableness. So Docile is born a tabula rasa ready to take the imprint of any ideology stamped on her. ${ }^{15}$ Girls, it seems, are seen not as subjects to be educated, but as automata to be directed - or in Docile's case repeatedly misdirected.

Docile's first tutor is a hermit who models an unambiguously frightful ideal of self-mortifying religion. As a result of his teaching, the unloved child thinks she would rather belong to the goddess Vishnu than to nobody and takes a vow to sit cross-legged without moving for seven years. Her mother fires the hermit and brings in a philosophe who re-programs Docile overnight with Enlightenment ideals of integrity, reason, and respect for the rights of others. Some of her teachers or misdirectors are written texts: Fenelon's Télémaque, Marie-Madeleine de Lafayette's La Princesse de Clèves, and Richardson's Pamela are chosen to imprint her with ideals of female silence, sincerity, and disinterestedness precisely because Montagu thinks they do not convincingly recommend these qualities. ${ }^{16}$ Docile, of course, learns her lessons to perfection, and they destroy her.

The schematic, lop-sided dichotomy of hermit and philosophe is followed by one more dichotomy before complexity sets in. Two maids of honour are appointed: la Comtesse de Bon Sens (the Countess of Good Sense) and la Marquise de l'Artifice. But whereas Lady Good Sense makes an abrupt departure from the story, Lady Artifice seduces the princess's affections under the guise of romantic friendship. In the first major emotional relationship of her life, Docile is wholly deceived. She loves and believes herself loved in return, but Artifice cares for nothing but her own material gain, and has no scruples about betraying her. Docile fathoms none of Artifice's concealment, and she repeats this pattern with a later, equally self-interested servant, and again with her greatest love and greatest betrayer, the ci-devant Chevalier Fortuné or Fortunate, later known as the Comte de l'Esperanza, Count Goodhope.

Secrecy and concealment first nurture, then destroy Docile's first experience of love. By a trick the marquise persuades the princess to

15. Romance Writings, 106-08.

16. Romance Writings, 108-11. 
make her a present of all her jewels. She feigns a secret sorrow which she makes every show of concealing until Docile, it seems, wrings from her with much difficulty the story that she needs money to rescue a brother from unmentionable distress. Docile, having no ready money, bestows her jewels - concealing her gift not only to protect herself, but also and more importantly to keep her friend's secret. So when her parents find out, she refuses to tell them what she did with the jewels, and they conclude that she is engaged in a shameful intrigue. Her heroism in friendship begins her fall into ill fame and victimhood, into imprisonment without trial as a state criminal. ${ }^{17}$

Later characters are less black-and-white than the maids of honour, but most are clearly identified as either bad or good. The High Priest is a politically powerful and malign presence. Well-intentioned young men well down the patriarchal scale, a guard and a soldier, in turn risk their lives (and lose them) in Docile's service. Philocles, a vision of male charms whom Docile falls in love with, is a feminised man of sensibility, the only character in the story who is capable of reciprocating her deep and passionate love. He turns out, however, not to be human, but a visitor from space, heir apparent to the ruler of the planet Venus. (Since Venus is apparently a planet of love and peace, he is also, like Docile, a potential victim.)

Not one but two differing characters represent forms of hedonistic gallantry, of love without fidelity and without regrets. The first of these, le Roi des Bons Enfants (King Goodchild) tries to persuade Docile to make her home in his innocently sensuous, pleasure-centred, almost prelapsarian kingdom; unlike others who love her, he never seeks to constrain her choice, but accepts her self-determination. A French Knight of Malta, encountered later, is libertine not in the style of nature, but in that of the dandy: fashionable, sophisticated, cosmopolitan, a devotee of the opera and of haute cuisine as well as of the ladies. It is his incredulity at Docile's story which allows her belatedly to understand that she can never convince her husband of the truth. Thus, ironically, an apostle of pleasure precipitates her final retirement as a vestal virgin.

The two male characters developed to greatest depth are le Prince Sombre (representing integrity with no sympathetic understanding),

17. Romance Writings, 112-20. 
who loves and disapproves of Docile and with whom she makes an unwilling, unhappy marriage, and Fortuné, later Esperanza or Goodhope (representing understanding with no integrity), who covets her, fakes Sombre's death in order to win her, and loses her when she discovers his deception. Sombre does not deceive, yet he is a victim of deception both in perversely believing Docile to be false and in swallowing every calumny against her as truth. Goodhope recognizes and loves Docile's truthfulness, yet sets out to win her through systematic deception.

Complex plotting surrounds these more complex characters. After her betrayal by Lady Artifice, Docile mounts the throne as successor to her father, but her integrity and benevolence make her reign short and unsuccessful. She loses her subjects' love by pardoning her enemies, dismissing her flatterers, instituting economy measures instead of raising taxes, slighting the Church, and offering no prospect of getting rich through corruption. While her actions make her unpopular, it is the calumnies against her as promiscuous and godless (spread by some for political reasons and by some for personal gain) that make her hated. The anti-Docile faction calls in foreign aid from the kingdom of le Roi Farouche (King Wildman). His son, Sombre, commands his force of military advisers with instructions to seek Docile's hand in marriage, but also to overthrow her rule. ${ }^{18}$

With Sombre the autobiographical element surfaces. Docile's parents are nothing like those of her creator, and Lady Mary had no prospect of inheriting an estate, far less a throne. Records of her early life do suggest traces both of a switch from religion to reason, and of a bruising episode of puppy love for a disillusioning object. But no reallife models are discernible for the hermit, the philosophe, or Ladies Good Sense and Artifice. Prince Sombre, on the other hand, a fictional character drawn with striking originality and psychological acuteness, is also inescapably drawn from Edward Wortley Montagu.

As the story demands, Sombre dutifully accepts the plot to deceive and betray Docile, but when he meets her he feels her ill repute may be exaggerated. His feelings make him drag his feet over the conspiracy, so that his father King Wildman orders the other conspirators to seize and imprison him as well as Docile. In this extremity he offers to

18. Romance Writings, 121-23. 
carry her off to a place of safety, having married her first for the sake of her honour. Sombre possesses, like the actual Wortley, "de l'honneur et de la Probité.... une Raison droite mais dure, une Jalousie qui alloit jusqu'a une defiance perpetuelle" (honour, probity, rigid reason, the makings of paranoia). ${ }^{19}$ He may be like Wortley too in his slowness to recognize that he is falling in love (as he has never done before because of his contempt for women). Yet he is also a type, a product of cultural forces, a man unable to develop "normal" heterosexual feelings because of the misogyny he has imbibed from his culture.

It is through jealousy that he realises, with horror, that he loves. "Une Prude devote devenûe amoureuse de son Palfrenier ne pouvoit pas estre plus outrée contre sa passion." "A pious Prude in love with her Stableman could not have been more outraged by her own passion; ${ }^{20}$ he was almost at the point of hating the person he loved; he could not forgive her for her Conquest, so he did everything he could to break his Chains." ${ }^{21}$ He does not imagine he could be jealous without just cause: she must be lewd and treacherous. It is only their imminent shared danger that draws from him a startlingly ungenerous marriage proposal: “je sçai que je suis l'objet de vostre Aversion. Je sçai encore plus, un autre.... n'importe; vous estes perdue si vous me refusez, et peut estre me sçaurez vous grê un jour, de vous avoir arrachée a... un Inclination qui vous deshonore" / "I know I am your aversion; I know that Another... but you are lost if you refuse me, and perhaps one day you will be glad I saved you from... an Inclination that dishonours you." 22

Docile feels his reproach is just: while he is nobly offering her rescue, she is indeed in love with someone else: Philocles, prince of Venus. She feels both culpable and humiliated by her inability to return what she takes to be generous love. The prince of Venus, handicapped by the humility and bashfulness of a sincere lover, does not proffer his hand or explain his identity until after she has committed herself to Sombre. The latter has spies busy gathering misinformation, and by the time he actually marries Docile he is certain that he is a cuckold. He repents of marrying, as he repented of proposing, at

19. Romance Writings, 224-25, 124.

20. I translated this "his," but it surely ought to be "her."

21. Romance Writings, 225, 124.

22. Romance Writings, 229, 129: ellipsis in original. 
the very moment of the act. When Docile, having once committed herself, strives to please and even to love him, he rebuffs her attempts. Her visible efforts to become the good wife she wishes to be, to offer him "the forms of tenderness," are to him further proofs of her deepdyed vice. ${ }^{23}$

One contrary to Sombre is Philocles, prince of Venus. Another is le Roi des Bons Enfants, whose title implies naiveté, open-heartedness, and in this case especially frankness, a total freedom from either concealment, or backbiting, or sexual hypocrisy. (The translation, Goodchild, could have been Flowerchild.) The king meets Docile by chance while her husband is out hunting (though Sombre always believes it was a planned rendezvous), and invites the couple to reside in his kingdom. There gallantry is the norm, but scandal unheard-of; literature consists of "Libertine Tales, Comic Operas, and light Comedies" while sentimental novels, theological or political controversy, and panegyric, are either banned or non-existent; religious services employ music, dance, and fragrance, but priests are compelled to remain illiterate; war is unknown except in self-defence. ${ }^{24}$

Sombre hates this permissive utopia, interpreting its customs as so many hypocritical masks for vice, but he pretends willingness to accept the king's invitation to stay there - while on the contrary compelling Docile to pretend she is uncomfortable and wishes to leave. She follows his instructions, departing first so that he can apparently leave in search of her. Although the local bylaws forbid calumny, and the Bons Enfants would never censure sexual behaviour, they agree in pitying Sombre for his wife's caprice, coldness, and discourtesy.

At this point, while involuntarily separated from her husband, Docile encounters Count Goodhope. He first sees her as a desirable minor conquest, then comes to value her more and more. He acts as her literary tutor, furnishes a mansion and country estate for her, finds and dresses a corpse to convince her that her spouse is dead, and even comes gradually round to a serious intention to marry her once she is out of mourning. Goodhope (as extraordinary a conception as King Goodchild) is a foundling. With no idea who his real parents were, he was taken in by a rich, uncultured bourgeois who educated him far

23. Romance Writings, 135-36.

24. Romance Writings, 139-41. 
above his station and left him a fortune. After school and the countinghouse came two years as a merchant in China, then the army, then a minor post at Court. Though just as self-seeking as Lady Artifice, he is far more delicately and tactfully so. "He regarded woman as a kind of Game animal made for man's amusement, to divert himself with, not to be bound to." ${ }^{25}$ Yet he has the art of remaining friends with his ex-mistresses and even with their husbands.

The very gradual shift in his relationship with Docile arouses reader expectations of his conversion from rake to hero. Finding her alone at an inn without funds, he behaves like a perfect gentleman. He modulates imperceptibly into the role of a lover until at last, to his own surprise, he comes to love indeed. Wary of frightening her by plain speaking, he conceals his intention of seducing her, and she responds warmly, as a romantic friend. While still concealing his plan for seduction he comes, gradually, to wish to marry her instead. Montagu must surely have had Richardson's Clarissa in mind here, but she never makes the allusion specific. More particularly she refrains from rewriting Clarissa with a happy ending, as so many did. The happy ending which seems tantalisingly in prospect rests on a lie, and vanishes when the truth comes out.

With the wedding approaching and Goodhope away making arrangements, the "widow" Docile receives word from her husband. He is alive, and so is her duty towards him. Though he is still collecting what he takes to be further proofs of her depravity, though she is heartbroken at the loss of dawning happiness, she sets out at once to return to him. And although her every action is presumed to be dictated by her inborn, predestined docility, still Montagu presents her anguish and her determination as responses to the battering currents of life. ${ }^{26}$

There follows an accelerating, powerful downward spiral. Docile dons male dress to ride away with her husband's messenger, takes ship, and is captured by Islamic pirates. The pirate ship is in turn captured by another ship under the command of a Knight of Malta. Docile brushes off yet another attempted male possessor: the Knight, like the Roi des Bons Enfants, seduces none but the willing, and there is never any chance that she will end up with him amid the delights of Paris.

25. Romance Writings, 150.

26. Romance Writings, 169-73. 
But the Knight's airy cynicism about gender relations makes her comprehend at last that her husband will never accept that a woman sought by other men can be blameless. Through him she sees herself with the eyes of the world, and once again she takes a decision and acts on it - she goes to immure herself among the order of vestal virgins. In burying her heroine alive, one suspects, Montagu returns to the covertly autobiographical.

In one of two fragments which she excluded from the final extant version of her work, her protagonist seriously considers a different path. In it Docile reverts to her early delight in study, now the study of astronomy, as if her choice of life might lead her to emulate the lady astronomer imagined by Fontenelle. ${ }^{27}$ The astronomy fragment is woven into the main narrative at its beginning: looking at the stars, the queen discloses a passion for learning more about the natural world, which the knight laughs at. There is no conclusion except the knight's satire on learned ladies. The life of study remains an idea, not an experience, not developed as an alternative to Docile's final choice of seclusion and deprivation.

This extraordinary novel (for novel it is, thanks to the inclusiveness of the genre) resists easy conclusions. Its initially programmatic, or programmed, heroine becomes a person of complex potential, even though her every course of action is intercepted and frustrated before she can carry it through. Her naiveté, although unique in its supernatural cause, yet links her to a whole line of English fictional heroines, from Richardson's Pamela through Lennox's Arabella and Burney's Evelina to Austen's Catherine Morland. The fairy gift reflects a social reality, the way girls are insulated from real experience and never told the truth. ${ }^{28}$

Aspects of the other characters comment with equal, slant, perceptiveness on other aspects of women's predicament. Count Goodhope points at the meritocratic possibilities open to a male though not to a female. A self-made man to a degree unheard-of in the novel at this date, he has none of those giveaway low-life tastes which generally cling to fictional characters risen from poverty. But without visible

27. Romance Writings, 274-76, 189-92. Bernard le Bovier de Fontenelle, Entretiens sur la pluralité des mondes (Paris, 1686).

28. In letters to her daughter, Montagu often reverted to the way girls are lied to and insulated from truth (Complete Letters, 2: 449, 451; 3: 26). 
trace of his origins, he bears no allegiance to the norms of the culture he has infiltrated. He sets his own norms. His capacity for taking infinite pains in pursuit of a woman reads like a comment on Richardson's Lovelace; like Lovelace, he is untouched by empathy for his intended victim. Yet unlike Lovelace he develops emotionally. He learns to prefer rational and social pleasure to sensual and aesthetic pleasure: an astonishing evolution which is never carried to completion.

Prince Sombre performs his only generous actions while he believes himself led astray by irrational feeling for a worthless woman. After each generous action his judgement (his misogyny) reasserts itself. $\mathrm{He}$ cannot learn or develop because he misinterprets everything to confirm and to nourish his existing opinion; so this exemplar of masculine integrity is unjust and treacherous towards his wife and lies to others on her account.

The originality of this work springs from rootedness in both French and English influences. Montagu devoured French books as readily as English ones, though her French was more fluent than correct. Her library was rich in French fiction of the late seventeenth century - to which she added some titles from the 1730 and 40 - and in English novels of the early eighteenth century (Jane Barker, Mary Davys, Eliza Haywood, Delarivier Manley are all represented ${ }^{29}$ and of the 1740s and 5os. "Docile"s relationships with all these are hard to untangle. It mentions Pamela, and writes back to Clarissa. Sarah Fielding's David Simple, I believe, is implicated in the general bleakness of its dogeat-dog world and more specifically when Docile "little knew that in seeking a faithful friend she was seeking, morally, the Philosophers' Stone." ${ }^{30}$

It is tempting to believe this philosophic tale was designed as a female counterpart to Candide and Rasselas. The three are close in genre and in outline (protagonist takes wide-ranging survey of human life, with discouraging conclusions), but radically different in tone. In "Docile" the heroine has personal reserves of potential enjoyment, both in virtuous action and in romantic love, although opportunities

29. Her only book by Penelope Aubin is a translation. Her book ownership is recorded in Wharncliffe MS 135 (Sheffield Central Library) and in the Sotheby's catalogue for 31 July 1928. See Isobel Grundy, "Books and the Woman: An EighteenthCentury Owner and Her Libraries," English Studies in Canada, $20: 1$ (Mar. 1994), 1-22. 30. Romance Writings, 126. 
for both are frustrated by universal wickedness and for the second by universal antifeminism. Candide presents human wickedness of a different order, not merely ruthless self-seeking, but energetic and ingenious cruelty on the part both of individuals and institutions. Rasselas is without large-scale human wickedness; it is the insufficiency of life to human aspirations that is the problem for Johnson. But direct relationship between these three texts is, on balance, unlikely. Montagu most probably composed "Docile" before her northern Italian exile ended in early 1756, while Candide and Rasselas did not appear until three years later. By 1759 Montagu had much less time on her hands: she was running two households and busy with social life - although her feud with the British Consul and Resident in Venice certainly gave her grounds for feeling discriminated against and persecuted. ${ }^{31}$

From the standpoint of English literary history this work looks like a fascinatingly exotic half-sibling of the works of Richardson and the Fieldings, but also like a throwback to a generation earlier. To begin with negatives: it does not tie its story to particular, definable settings in the manner of English novels of the 1740s, but takes place (like fairy tales, oriental tales, and the English fiction of Lady Mary's youth) in regions appropriated exclusively to fiction. Its leading characters are aristocrats. Social realism is not its mode, though psychological realism is.

Its approach to women and sexuality is more like French than English fiction. Montagu's heroine is open to sexual feelings (not only for the unique beloved object) in a way that Richardson-Fielding heroines are not. Docile is never lusciously described in the manner of an Eliza Haywood heroine; her capacity for feeling is situated as a character trait, even one of her gifts or talents, not linked with her beauty as part of her physical attributes: "Elle étoit née tres vive, elle avoit la memoire la plus heureuse, le Cœur parfaittement bien fait, et un grand fond de tendresse." 32 She experiences passionate same-sex love before she reaches marriageable age. Meeting the beautiful Philocles, she at once begins to dream ("rever," to entertain sexual fantasy, just as the Count later does about her after his most successful stratagem against

31. Isobel Grundy, Lady Mary Wortley Montagu, Comet of the Enlightenment (Oxford: Clarendon, 1999), 571, 574, 581-82.

32. Romance Writings, 213. 
her). ${ }^{33}$ Montagu handles Docile's dreaming by stepping back like Henry Fielding from narrator to commentator, to caution any prudes among her readers. Even they, she says, must have felt that power of sympathy which sets Docile dreaming "of a young man whom she hardly knew, and who seemed to be of a rank well below her own.... it is enough for the Queen's virtue that she should fail to recognize her own sentiments, and that she should struggle against them in proportion as she began to understand them." Docile loves the prince of Venus with blushes, embarrassment, "pleasure mingled with shame," and futile attempts at concealment. His face "troubled her repose," though she is so inexperienced as to suppose that his evident confusion in her presence means that he dislikes her. ${ }^{34}$ Her erotic response has neither the seductiveness of Haywood nor the verbal indirection of Richardson; unlike the responsiveness of Fielding's heroines, its psychological effects are registered and examined.

Although Docile remains perpetually at the mercy of other characters, as a picaro and as a queen in exile she occupies the centre of her story, as Richardson's first two heroines do and Henry Fielding's do not. (Sarah Fielding's first novel chooses a male protagonist to address the topic of human depravity.) Docile's troubles are "female difficulties" that did not take centre stage in the English novel until later, long after the time when feminist elements dominated French fiction, as Joan DeJean has powerfully shown. "For a brief time in seventeenthcentury France, women walked with unbound feet." 35 French fictional heroines at that time were inspired by real-life warrior princesses like La Grande Mademoiselle; fiction was closely linked with the salons of powerful women; women writers mounted a critique of marriage and several of them lived outside it. In 1697 Bayle's Dictionnaire historique et critique - registering the renown of Madeleine de Scudéry, MarieCatherine de Villedieu, Marie-Madeleine de Lafayette, and their ally Jean Renaud de Segrais - pronounced that the "best French novels have for some time been written by... women." 36 The abbé Huet in his literary-critical preface to Lafayette's Zayde attributes the supremacy

33. Romance Writings, 127, 160, 227, 253.

34. Romance Writings, 127.

35. Joan DeJean, Tender Geographies: Women and the Origins of the Novel in France (New York, London: Columbia UP, 1991), 9.

36. DeJean, 162. 
of the French novel to the freedom enjoyed by French women. ${ }^{37}$ This was the French fiction of Lady Mary's youth, but she was equally well acquainted with that of later decades during which, for instance, Father Charles Gabriel Porée attacked the genre in 1736 as reversing the natural order and making women important. After this, DeJean argues, women were written out of the official history of the novel in France. The trend accelerated after the Revolution, but the earlier stages took place within Montagu's career as reader and writer. ${ }^{38}$

Montagu was alert to anti-feminism in literary history as elsewhere, but her grounding in the seventeenth-century French novel meant that to her the form was female in a way that, after the 1740s, the canonical novel in England was not. ${ }^{39}$ The French tradition not only offered the basic sub-genre of memoir-as-fiction or fiction-as-memoir, but also paralleled the topics that Montagu treats in "Docile." The protagonist of Villedieu's Memoirs de Henriette-Sylvie de Molière (1672-74, a pioneer of the sub-genre) writes self-defensively "in the midst of all the evil stories by which my reputation is slandered everywhere." ${ }^{\prime 0} \mathrm{~A}$ jealous, accusing husband makes the heroine unwillingly notorious in the comtesse de Murat's Memoires de Madame la comtesse de $M^{*}{ }^{*}{ }^{2}$, 1697 (which DeJean calls a novelization of actual experience, ${ }^{41}$ and which takes a jaundiced view of romantic love). In Scudéry's Artamene, ou Le grand Cyrus (which Lady Mary's earliest fictional heroine reads late into the night $)^{42}$ the character called Sapho chooses exile and sees marriage as slavery. All these novels or romances (copies of which Montagu owned) engage with the predicament of the upper-class woman, highly visible but vulnerable to scandal, living in a world of intrigue and disguise. This, for her, was close to home. Throughout her life almost everything she did proved to be offensive to somebody.

37. DeJean, 174 .

38. DeJean, 91, $184 \mathrm{ff}$.

39. Gillian Dow's collection Translators, Interpreters, Mediators: Women Writers 1700-1900 (Oxford: Peter Lang, 2007) puts forward convincing arguments, however, for the important influence of French fiction on English women writers.

40. Madame de Villedieu (Marie-Catherine Desjardins), Memoirs of the Life of Henriette-Sylvie de Molière: A Novel, ed. and transl. Donna Kuizenga (Chicago and London: U of Chicago P, 2004), 26.

41. DeJean,143. Montagu owned Julie-Henriette de Castlenau, comtesse de

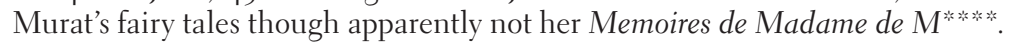

42. Lady Mary Pierrepont, The Adventurer, c. 1704 (Edmonton, AB: Juvenilia P, 2000), 7 . 
Her writing, her cross-class friendships, her political activity, her inoculation campaign, even her style of dress, were all "obnoxious to each carping tongue," as Anne Bradstreet puts it. ${ }^{43}$

French fairy stories (often featuring and often named from imaginary princesses) are as relevant to "Docile" as fictional court memoirs. As Ellen Welch remarks, they "permitted authors to propose marvellous twists on all kinds of social norms - monarchal sovereignty, gender relations, and family structures - without risk of censorship." ${ }^{44}$ Of these too Lady Mary owned editions from the 1690 or or thereabouts, probably familiar from childhood: Charles Perrault, Marie-Catherine d'Aulnoy (both very popular in England as well as France), Charlotte-Rose de Caumont de La Force, and, again, the comtesse de Murat. ${ }^{45}$ She also owned a clutch of French fairy-tale volumes from the 1730s and 4Os. Like the court fictions, fairy-tales from different generations are connected by winding and branching channels of inter-relationship. The modern scholarly editor of the mysterious $\mathrm{M}^{\text {lle }}$ de Lubert writes that her "La Princesse Lionnette et le Prince Coquerico" (another title which Montagu owned) re-casts motifs from at least four of her predecessors. $^{46}$

"Princess Docile" does the same kind of re-casting. It features a royal only child, fairy gifts, quests which hustle the protagonist from one kingdom to another, exotic imaginary cultures (the Royaume des Bons Enfants might dimly recall the Peaceful Island in de Murat's fairy tales, or the "île des Plaisirs tranquilles" in d'Aulnoy's "Le Prince Lutin"). But such motifs are simpler and more plot-directed in the fairy-tales: the île des plaisirs tranquilles is a society of virgins who have resolved to have no contact with men, and after the prince obtains access in the form of a parrot he duly persuades their princess-ruler to marry him. The île (with its orthodox concept of a virgin life super-

43. Anne Bradstreet, "The Prologue" in The Tenth Muse Lately Sprung up in America, or Severall Poems, compiled with great variety of wit and learning, full of delight (London: Stephen Bowtell, 1650), 4.

44. Ellen Welch, “Une fée moderne': An Unpublished Fairy Tale by la Comtesse de Murat," Eighteenth Century Fiction, 18.4 (2006) 499-510.

45. Including Perrault's Contes de ma mere l'oye (Paris 1697), d'Aulnoy's Contes nouveaux (Paris 1698), and La Force's Les Fées, contes de contes and de Murat's Nouveau recueuil des contes de fées (Paris, 1698).

46. $\mathrm{M}^{\text {lle }}$ Lubert, Contes, ed. Aurélie Zygel-Basso (Paris: Editions Champions, 2005), 548-49. 
seded by the higher option of marriage) is created, sustained, and dismantled by magic, whereas in "Docile" the magic is strictly limited and the ambivalent, troubling Royaume des Bons Enfants survives the heroine's departure. ${ }^{47}$

So this unclassifiable, hybrid text draws on both English and French literary history while fitting into neither. At the end, Docile faces something rather like a choice of Hercules, between pleasure and duty: to go off to fashionable Paris with the Knight of Malta or to go back to the husband who, she now realises, will always see her as a scheming, promiscuous monster. (The option of returning to the beloved whom she has left for reasons of conscience is never raised: conscience still forbids it.) Instead, she chooses a life of mortification: she "passa sa vie en des Austeritez plus cruels que ceux d'une Carmelite, avec la Reputation d'une Messaline": "she spent her life in Penances harsher than those of a Carmelite, but her Reputation was that of a Messalina." 48 This reverses the fate of de Lafayette's princesse de Clèves, whose renunciation of the world and particularly the flesh wins her a saintly reputation. I know of no ending in English and French literature to match this defeat of female autonomy.

The manuscript of this work survives in Montagu's late hand (apart from some short sections written by a scribe). As mentioned above, it probably dates from the decade ending in 1756 , which was that of her dubious and hidden involvement with Count Ugolino Palazzi. This seems not to have been any kind of love-affair, but the bullying and exploitation of an older woman by a macho and violent man who used emotional as well as actual weapons. Palazzi won her confidence by the genuine and valuable service of safe escort through a war zone (an episode which suggests several in "Docile"). Thereafter he practised extortion: renting or selling Lady Mary properties that he wished to dispose of, and virtuoso scams such as having her jewels stolen and then demanding money to pursue the allegedly unidentified thieves. She kept her persecution carefully hidden from her daughter in England, but once it was over she related it secretly in another riddling document cloaked by a foreign language, the "Italian Memoir."

47. Parallelled in Shakespeare's Love's Labour's Lost and in "The Convent of Pleasure" by Margaret Cavendish, Duchess of Newcastle.

48. Romance Writings, 273, 187.

49. Romance Writings, 81-105. 
"Princess Docile" and the "Italian Memoir" are both esoteric personal statements. In autumn 1752 Montagu was working on a "History of my own Time" which (she assured her potentially disapproving daughter) she destroyed, quire by quire, as soon as it was finished..$^{50}$ She refrained from destroying "Docile," or the "Italian Memoir," or some shorter prose fictions (among them a pair of tales from a cycle set at the French court, which spotlight a rake-villain who first ruins his sister's illicit love-affair, then seduces and ruins an innocent young woman)..$^{51}$ These further offspring of the French tradition embody anger against the destructive male and psychological insight into the minds of women in love. They deserve much more attention than they have received, but without the autobiographical element they have one fewer layer of complexity than "Docile."

Montagu seems not to have circulated either the "Italian Memoir" or any of the late fictions among her friends, as she did with her poetry and essays. Nor did she deposit them as a legacy for safe keeping, implicitly for publication, as she did her Embassy Letters. ${ }^{52}$ At least she refrained from burning them, as she says she burned her history without benefit of fiction. If she did indeed deliberately bury "Princess Docile," the action was of a piece - as is the novel itself - with comments she made throughout her life about the disparity between her reputation and her actual behaviour. Lies, secrets, and silence. We must be glad of the veil of fiction which at least seems to have preserved this work. This veil enabled her to depict the effects of erasure rather than to erase.

50. Complete Letters, 3: 18-19.

51. Romance Writings, 28-80.

52. Grundy, Lady Mary Wortley Montagu, Comet of the Enlightenment, 611-12. 